\title{
Environmental Limits of Personal Freedom
}

\author{
Richard St'ahel \\ Constantine the Philosopher University, SK
}

SŤAHEL, R.: Environmental Limits of Personal Freedom.

Philosophica Critica, vol. 2, 2016, no. 1, ISSN 1339-8970, pp. 3-21.

The more the number of people who live on Earth grows, the more significant are the cuts individuals must accept in realization of their own freedom, so as not to limit the freedom of others. With the growing population on the finite planet the real space for freedom of each individual decreases. Moreover, the growth of complexity of the global industrial civilization increases the degree of interdependence on one hand, on the other the degree of mutual trust decreases as a result of the imperative of growth and profit, and without it no human society can function in the long term. Access to sources necessary for the realization of fundamental freedoms is unequal, and, in fact, it thus limits its accessibility for the majority of human population. Philosophical reflection then should cope with question, whether the range of guaranteed freedoms can be broadened or at least sustained when the space for its realization with the growing human population struggling for increasingly limited resources narrows.

Key words: Freedom - Imperatives of growth - Limits of growth - Natural resources

There are some unfortunate circumstances where one's liberty can be preserved only at the expense of someone else's, and where the citizen can be perfectly free only if the slave is completely enslaved.

J.-J. Rousseau ${ }^{1}$

1 (Rousseau 2011, 220). 
Refugees looking for all sorts of ways of getting into Europe were one of the main topics of public discourse in most European countries in 2015. Debt crisis in Greece was pushed into the background by the migration crisis. EU member states face conflict of its own politics. On the one hand they always emphasize the importance of universal human rights, on the other they are trying to stop, or at least mitigate the mass flow of refugees and immigrants. As Ulrich Beck wrote few years before the current immigration crisis broke out: "The wealthy democracies carry the banner of human rights to the furthest corners of the earth without noticing that the national border defenses, with which they want to repel the streams of migrants, thereby lose their legitimation. Many migrants take seriously the proclaimed human right of equality of mobility and encounter countries and states that - not least under the impact of increasing internal inequalities - want the norm of equality to stop short at their fortified borders" (Beck 2010b, 168). Despite that, European Union still declares freedom of movement as one of its basic pillars. Contradiction of free movement of capital and restricted freedom for relocation of work force has been increasingly manifested even in the growing stream of people trying to get from developing to developed countries or regions at any price. This internal contradiction of global capitalist system has been deepened even by the widely used rhetoric of equality as a fundamental thesis of human rights concept which stands in clear contrast to everyday experience of majority of humanity ${ }^{2}$.

No matter if people migrate for work, because of war or because of climate change; they all believe that freedom of movement as one of the most obvious demonstrations of personal freedom is also their fundamental right. However, its realization contradicts not only the unwillingness of rich countries to give this right really to all people, but also the impossibility given by spatial environmental limits. ${ }^{3}$ Thus, the concept of human rights and freedoms is an important civi-

2 In reality, as Robinson emphasizes: "Yet workers do not enjoy the transnational mobility that capital and capitalists have achieved." (Robinson 2014, 51)

${ }^{3}$ Requests of environmental or climatic refugees for asylum are rejected because they are not politically persecuted; only their environment has changed to such an extent it doesn't allow simple physical reproduction of all members of the local community. However, international agreements or national legislations do not regard these as reasons to grant asylum. The Convention relating to the Status of Refugees, also known as the 1951 Refugee Convention, doesn't define the term climatic refugee. See (UN 1951). International Organization for Migration estimates that the number of so-called environmental migrants or climatic refugees will increase to 200 million by 2050. Other estimates say that approximately a billion people will be affected by the climatic changes. But fast melting alpine glaciers only in Himalayas threaten almost 2 billion people living in river basins of rivers fed by these glaciers. The threat lies in the lack of drinking water and in the inability to produce food because growing basic food depends mostly on the river water. If this threat should become real it would very likely lead to a mass migration. This could lead to vio- 
lizational achievement, but the realization of many human rights altogether with the right of equality of mobility, or simply freedom of movement is now endangered by the crisis of global industrial civilization, or in L. Sklair's words, by two crises - crisis of class polarization and that of ecological unsustainability (Sklair 2009, 83).

\section{Rights and threats}

Above mentioned crises do not endanger only the realization of freedom of movement but also the conditions of further existence of global industrial civilization or humanity as such. So, the current task is not only about biological survival of humankind as one of the biological species, it's also about preserving the civilization. To preserve the civilization means to keep not only the level of scientific and technical knowledge, but also the level of recognition and real accessibility of human rights and freedoms. We can even suggest that the crisis of the global industrial civilization primarily threatens human rights and freedoms. And this is not only because "individual freedom came to mean individualized consumption in a consumer society, and consumer freedom within the framework of the market mechanism became a means of self-realisation and individual independence" (Hohoš 2007, 42), but also because the consumption of the richer part of the world population can grow only at the expense of freedom, or rather at the expense of the freedom to choose even basic living conditions of others. In the conditions of our finite planet it is becoming more and more apparent that the more resources $^{4}$ and space for realization of one's freedom one part of the population claims, the less resources and space for realization of basic freedom is left for the rest of humanity. Therefore, we need to ask: Do we need to control the consumption and also movement of people in order to protect freedom?

The connection of the concept of human rights and freedoms with the condition of nature and the environment, in which the struggles for human rights and freedoms take place, has become a part of environmental thinking in the early 1970s. Even the Declaration of the United Nations Conference on the Human Environment, adopted in Stockholm in 1972, states that the environment is one of the essential conditions for humankind to enjoy basic human rights, including the right to life itself. The document defines protection and improvement of the human environment as "the duty of all Governments" (UN 1973, 3).

lence that would destabilize the whole region. Large areas with big population at the foothills of South American Andes also depend on the water from alpine glaciers and there are other similar areas.

${ }^{4}$ Resources are "basic material, energy and process conditions of life that are irretrievable” (Cílek 2012, 769). 
The concept of human rights and freedoms is an important civilization achievement regardless of its theoretical and practical problems. Criticism of this concept points out that „our civilization doesn't have a thought process to justify the concept of human rights that would be accepted on a larger scale" (Sousedík 2010, 9) and so on one hand we have "a crisis of justification" and on the other "always new 'human rights' are required" (Sousedík 2010, 13). Other authors point out that "the concept of human rights is in a way an ideology and as such is perceived in some cultural circles outside Europe" (Šmihula 2001, 433). Habermas's observation according to which "human rights policy becomes a mere fig leaf and vehicle for imposing major power interests" (Habermas 2012, 97) is often subjected to criticism. Despite this we can agree with Habermas's suggestion that the "human rights constitute a realistic utopia ... anchor the ideal of a just society in the institutions of constitutional states themselves" (Habermas 2012, 97). The concept of human rights can be considered as a normative idea that has many times been expressed in particular legal norms on national and international levels.

In the present situation, which in consequence of the globalization processes cannot be characterized as a system of relations between sovereign subjects of international law anymore and has not formed a transnational or cosmopolitan system yet, "human rights provide the only legitimization base accepted by all" for the policy of the community of nations, because "almost all governments accepted the Charter of the United Nations, which in the meantime have undergone some changes. Universal validity, the contents and order of human rights are despite this fact still problematic" (Habermas 2008, 120). However, the concept of human rights expressed in The Universal Declaration of Human Rights can be a base for a consensus without which the necessary global agreements on protection of preconditions and conditions for life cannot be accepted and thus corresponding political and legislative steps cannot be taken. The problem of the contents and order of human rights lies in the fact, that in different areas and for different reasons various phenomena are considered to be the most serious threats to life and human dignity. The consensus on basic human rights should be the one to be reached the most easily. It includes the right to life, the rights to safe water, to adequate food, to sound housing, to access to means of choosing the size of their families (UN 1987). But realization of these rights is threatened by the environmental crisis of the global civilization.

One of the consequences of capitalist globalization is that these rights are understood as social claims which are in conflict with the system imperative of profit maximization. If at present "the human rights are generally understood as claims reciprocally admitted by human subjects for a guarantee of life that corresponds with necessary conditions of 'dignity' or 'respect', while the view that the opportunity of human existence belongs to minimal requirements to the morality of social coexistence is central to this understanding" (Honneth 2008, 
101), then due to the fact that the possibility of human existence is determined not only by a set of social, but also (and even primarily) by a set of environmental conditions and relations, we can understand basic human rights also as rights to basic conditions of life. We can even assert that, in general, it is a right to a dignified life; a life not reduced to a mere survival or even everyday struggle for survival.

Habermas notes that the term human rights was created by a synthesis of rationally justified morals and positively constituted law that "served absolutist rulers or the traditional assemblies of estates as an instrument for constructing the institutions of the modern state and a market society. The concept of human rights is a product of an improbable synthesis of these two elements. 'Human dignity' served as a conceptual hinge in establishing this connection (Habermas $2012,83)$. In this connection L. Hohoš states that at present "these are two interwoven disputable problems - normative goals that can be solved only globally - new, more just rules of the world trade or the world market and the limitation of the present ecological crisis so that it does not become an irreversible catastrophe. Current uncompromising criticism of neoliberalism does not include the rejection of liberalism in its defense of individual freedom" (Hohoš 2013, 4950). Personal freedom is precisely the one which is intensively threatened by the recent crises of class polarization and ecological unsustainability even to the extent that it is once again becoming a privilege only of members of the transnational capitalist class rather than a generally available fundamental freedom. If freedom, especially personal freedom, is not generally available to the entire human population, it becomes de facto a privilege of those groups or individuals who really dispose of personal freedom.

One of the main inspirators of modern understanding of freedom and of the idea of inalienable human rights was J.-J. Rousseau. According to him, freedom comes from the human nature. At the same time "its first law is to see to his preservation" (Rousseau 2011, 157). From this point of view his concept can be taken as an inspiration also in today's situation, because Rousseau insisted on the fact, that human freedom is a basic determination of a man and in an argument with J. Locke he eliminated the possibility of legitimizing slavery. It was this situation when he talked about inalienable human rights. He understood human freedom as independence, and freedom is freedom only if it is accessible for everyone, not only for the privileged. Moreover, he pointed out that social inequality deepens in a consequence of an unequal access to resources, mainly to land. He also pointed out the finite fertility of land, in other words the total quantity of food that can be grown on it, by which he also anticipated the need to reflect on the environmental conditions and limits of a political system and freedoms, which can enable and protect such a system. Rousseau thus gives a valuable basis and provides impulses for reflection on the current global environ- 
mental crisis which threatens also the stability of political systems that enable the realization of the concept of human rights and freedoms.

With the continuous globalization and integration of the global industrial civilization the reciprocal dependency ratio of states and people increases, so that the majority of individuals are not able to realize its extent. A. Naess in this connection states that "self-sufficiency of individuals and local communities decreases according to how technology exceeds their abilities and resources" (Naess $1996,153)$. By this, he connects environmental and social costs of a society with its political and economic system and the freedom it can provide. In his concept, self-sufficiency is the condition of freedom, because this is the only thing that enables independency, without which we cannot talk about real freedom. Development of technology increases possibilities of free actions, free communication or mobility, but does so also in case of possibilities of controlling and manipulation of actions of individuals and the whole population. The human population grows and so do consumption expectations of individuals. These processes happen within the closed planetary ecosystem with the finite quantity of all resources, without which the civilization cannot continue and the survival of humanity as a biological specie is impossible. Many crisis phenomena today manifest these contradictions ${ }^{5}$, expose the fact that the current civilization processes collide with the finite planetary resources and so with the possibilities of growth. Therefore, current situation exemplifies "crisis that is approaching systemic proportions, threatens the ability of billions of people to survive" (Robinson 2014, 5), or as Robinson writes: "The system is fast reaching the ecological limits of its reproduction" (Robinson 2014, 17).

\section{Defense or expansion of human rights}

Despite the above mentioned problems and crises tendencies, current political discourse is dominated by the problem of expansion of human rights, primarily of certain freedoms and moreover, only in certain parts of the world. So in Rousseau's understanding of freedom as independence it would be more appropriate to talk about a real narrowing of freedom space. The bigger the number of people living on Earth, the more individuals must limit themselves so that by realizing one's freedom they wouldn't limit freedom of others, as long as their freedom isn't to be a privilege at the expense of other people from their commu-

\footnotetext{
${ }^{5}$ The imperative of growth is in contradiction with the limits of growth, so the growth (economic and of population) is therefore from a long-term perspective unsustainable and literally self-destructive. The more intensive growth we reach, the shorter period it will be sustainable. For more about the concept of imperative of sustainability see (St'ahel 2016).
} 
nity and also at the expense of people from other countries, often from the other side of the world. If we accept Rousseau's requirement for equal freedom for every human being, we must admit that with the growing human population the possibility of each individual to realize herself decreases. The possibilities to realize the constitutionally enshrined freedoms are limited, e.g. by economic or environmental limits or by application of the principle "my freedom ends where another person's freedom begins". Here they become formal freedoms. Deepening the contradiction between the formally guaranteed freedoms and (im)possibilities of their realization increases social tension which can lead to an open internal conflict within society and so to a collapse of social system.

It is necessary to note that no later than after WW2 governments have taken the responsibility 6 to create and maintain the conditions for realizing human rights, so that they would be accessible to all people in a particular state. The universalist interpretation of the human rights concept theoretically implies an effort to create and maintain the conditions for realization of human rights everywhere in the world, i.e. also outside the jurisdiction of the state. In fact, realization of human rights depends mainly on the willingness and also on the ability of individual states to reflect the concept of human rights into their legislation and to assist to its real availability, or if it is necessary, to defend it - at least for the people on the territory controlled by the specific state. And so the responsibility to implement and protect human rights still lies with individual states despite many international organizations working in this area. ${ }^{7}$ To incorporate the right to life into constitutional documents then can mean to transfer the responsibility for people's security to the state. It is an internal security provided by the police and other organs and external security provided by diplomacy and army. If the right to life is really a basic human right and even without complicated argumentation it is clear that a life is not possible without water and food and breathable air, ${ }^{8}$ i.e. without the favorable environment, then it is also clear that the state cannot give

\footnotetext{
${ }^{6}$ By acceding to treaties such as the Universal Declaration of Human Rights (UN 1948), the International Covenant on Civil and Political Rights (UN 1966a) and the International Covenant on Economic, Social and Cultural Rights (UN 1966b), in spite of the fact that: "It is essential to realize that ratified human rights in international documents are so far a claim which has not yet quite been achieved. That is exactly why we talk about fundamental human rights which should be fulfilled and achieved first" (Hrubec 2010, 201).

7 "According to the type of human rights we mean the primary carrier of complementary duties changes: although these rights have to be understood so that they exist based on their intersubjective nature to all other people and the individual duties that correspond with it; but usually these duties can be fulfilled only if they are transferred to mutually established state organs. Primary addressees on which the demands of human rights are placed then are then governments of individual states" (Honneth 2008, 101).

${ }^{8}$ See (Kohák 1993).
} 
up its responsibility to maintain the environment in such a quality which would make a human life possible. In other words: the right to life as a basic human right is less and less thinkable without the favorable environment, which includes the right to breathable air, drinking water and at least a minimum of food and a minimal space for living.

An effort to realize these rights collides with the finite resources without which these rights cannot be realized. The right to water and food, as well as the right to housing are enshrined in international treaties. These agreements order states to respect and protect these rights and to fulfill them, but the continuous degradation of the environment ${ }^{9}$ slowly reduces possibilities to fulfill and protect these rights. However, neither the governments and international organizations (created by them), nor multinational companies have changed their basic organizational imperatives, mainly the imperative of growth application which imposes most serious limits in fulfilling the above mentioned human rights and freedoms. The ability of the governments to fulfill obligations and expectations based on the concept of human rights, which is enshrined in the constitutional systems, will threaten the political legitimacy and the stability even of those states that have so far had the technological and economic power allowing them to provide their citizens with quite a high extent of military and non-military security or free access to water and food resources. However, instead of it there are world spread processes of commodification of resources and privatization of public services and companies, which were primarily created for providing precondition for realization of basic rights and were not supposed to be competitive on global market.

The growing negative influence of the climatic changes on the ability of states to fulfill the right of their inhabitants to water and food ${ }^{10}$ will very likely increase the temptation of state and non-state players to secure their own security (resources, energy, food) at the expense of others or it will provide these aspects of sucurity only for their inhabitants or only for a selected group. The first victims of this arrangement are environmental refugees and also groups of socially exclud-

\footnotetext{
${ }^{9}$ Mainly the processes such as a climate change, biosphere integrity (earlier biodiversity loss), novel entities (earlier chemical pollution), stratospheric ozone depletion, ocean acidification, biogeochemical flows (linkage between phosphorus and nitrogen cycles), landsystem change (deforestation, forest degradation and agricultural practices), freshwater use (overexploitation of water resources) and atmospheric aerosol loading. See (Steffen 2015).

${ }^{10}$ For example fast melting of alpine glaciers in Himalayas threatens almost 2 billion people living in river basins of rivers fed by these glaciers. The threat lies in the lack of drinking water and the inability to produce food, because growing basic food depends mostly on the river water. If this threat should become real, it would very likely lead to a mass migration of hundreds of thousands people. This could lead to violence that would destabilize the whole region.
} 
ed people from the rich Global North. As M. Hrubec states "an important aspect of human rights is not just their formulation but also their active implementation in history" (Hrubec 2010, 195). Implementation of human rights would mean a radical reassessment of economic and political priorities as well as of technical norms and technological process. The alternative to this fundamental reassessment is a gradual resignation to the concept of human rights or transformation of some human rights to privileges for a certain part of the population. In the atmosphere of high expectations that the concept of human rights has created in the last 50 years would be very difficult to legitimize such transformation. U. Beck even warns, that "the collision of growing global expectations of equality (human rights) and growing global and national inequalities, on the one hand, namely with the radically unequal consequences of climate change and the consumption of resources, on the other, could soon sweep away this whole set of premises of a nationally confined inequality" (Beck 2010a, 258).

\section{Freedom of movement as manifestation of personal freedom}

The best example of how the growing population and its increasing consumption expectation threaten even the most basic freedoms is the freedom of movement. It is the most visible and the most basic aspect of personal freedom a person can have an immediate experience with. ${ }^{11}$ Moreover, in Central and Eastern Europe this freedom is even nowadays considered to be the most visible proof of freedom, because one of the most discussed signs of oppression in the totalitarian regimes was a travel ban to other countries, or rather a restriction of this freedom, where only privileged were allowed to travel freely. ${ }^{12} \mathrm{~A}$. Swift also chooses this example in his analysis of different possibilities of understanding freedom in political philosophy (Swift 2005, 62-64). Swift shows that traditional political philosophy discusses mainly the legal and social aspect of the freedom of move-

${ }^{11}$ Laying aside that countries which assert the freedom of movement as a part of universal human rights and criticize or even sanction countries that don't guarantee this freedom at the same time hinder the freedom of movement by limiting the entry of citizens of mostly the poor countries by a system of visas or by criminalizing immigrants and refugees that came to their country without a required permit.

12 Current surveys show that a big part of population considers the opportunity to travel without permits and border control to be one of the main assets of the change in 1989. The freedom of movement is also one of the legitimizing arguments of the political regime after the November 1989 in which the decrease of social rights is trivialized exactly by highlighting the possibility to travel, study or work abroad. Towards the domination of radical neoliberalism in the public discourse in V4-Countries - especially in Slovakia - during the last two decades see (Dunaj 2014) and (Dunaj 2015). 
ment. It (political philosophy) is concerned with a question if this freedom is restricted only in case the laws ban to leave the country or if a possibility to travel is restricted only by sufficient finances that one needs for traveling. Political philosophy hasn't considered the environmental restriction of the freedom of movement yet. Even the countries considering the freedom of movement to be absolutely unquestionable are taking steps towards legislative restrictions with respect to environmental consequences of its mass assertion. For example are applied in many national parks - certain areas are closed or the number of visitors per year is limited. Traffic jams are frequent not only in cities or on highways but more and more in ship or air transport. This is a consequence of a perception that the freedom of movement is a freedom of unrestricted consumption of fuels (oil products), of the products of automobile, aircraft and shipbuilding industries as well as of the tourist industry or services provided by a network of highways, airport and sea or river ports - all regardless of their social or environmental consequences. Many countries therefore take action that can be perceived as restrictions of the freedom of movement although networks of highways and size of ports or airports are growing. Acute worsening of local air (so-called smog alarms) or traffic collapses on full highways force the local authorities to restrict individual transport and thus the freedom of movement. As D. Špirko says: "Responsibility is connected with the freedom of acts, but the freedom of acts is not so closely connected with responsibility" (Špirko 2012,183). This means that responsible behavior, in the case of the freedom of movement as well, must be enforced by an administration restriction and a control of its observance. All this is done in order to have at least a certain level of the freedom of movement to be available to all.

Every year in the beginning of summer holidays there are several hundred $\mathrm{km}$ long traffic jams because thousands of people start out for their holiday destinations. Realization of their freedom of movement is restricted not only for those who travel, but for all who need to use the network of highways. Moreover, the consumption of oil products increases ${ }^{13}$ and so does pollution and amount of exhausted climate change gases. This doesn't only restrict the realization of the

13 The oil crisis in 1973 in Western Europe and the USA proved that the possibility to realize the freedom of movement depends on the sufficiency of oil products. Their lack limited the possibility to travel but governments then legislatively limited the freedom of movement. They limited purchases of oil products for individuals and legal persons or even banned using automobiles on certain days. The purpose of these precautions was a public interest - to have a reserve for the police, firemen and paramedics. This can be interpreted as Hobbesian limitation of freedom in the interest of security. Legislative limitation of the freedom of movement in cars in nature areas, in city centers or in time of high pollution of the environment is also justified by the public interest. Personal freedoms of drivers have to give in to the right to health and as a consequence to life of others as well. 
freedom of movement; it also damages health of people who stayed at home. The same applies to aviation which has a similar devastating influence on the global climate and the quality of air. These types of transport use inhabitants of richer countries of the world which compose a little less than 20 per cent of the world population. If the same freedom "to travel" to holiday resorts each year applied inhabitants of China, India, or many other countries, who cannot afford it, the consumption of oil products and the production of greenhouse and other toxic gases would skyrocket. It would also lead to a collapse of many ecosystems which are simply not able to endure so many visitors. In the near future we can therefore expect the freedom of movement to be restricted with regard to its environmental consequences that restrict freedoms and rights of others. In this overpopulated world we only have these - defined by Rousseau - restricted civil freedoms that must take freedom of others into consideration.

\section{Environmental determination}

Freedom is then determined not only politically and economically, but also environmentally and biologically. Traditional reflection on politics, law and state has so far dealt mainly with political and economic freedoms, their extent or restrictions. It has either overlooked their environmental preconditions and limits, or it hasn't reckoned them as worthy of systematic and deeper reflection.

If we accept the fact, that most of the human activities depend on the laws of nature, the principles on which the industrial civilization and its political and economic system are built cannot ignore them. Civilization dependence on a specific condition of biosphere has already been proven and, therefore, in order for the civilization to survive the principles on which it builds its institutions and imperatives should be adapted accordingly. The traditional definitions of several kinds of freedom should be thought over from this point of view.

Divergent processes that deepen conflicts in our society should become the subject of philosophical reflection. On the one hand, there is a process of extending legally guaranteed freedoms, on the other, there is a process restricting possibilities of their true realizations. And at the same time we can identify efforts to broaden freedoms at the expense of the equal access to those resources that allow their fulfillment. These phenomena appear in a situation in which the technological development and economic integration in globalization processes increases complexity of the industrial civilization. The higher is the level of complexity, the deeper are the reciprocal conditionalities which do not broaden but restrict the possibilities to realize these freedoms. If these trends continue, we can expect that the tendencies to restrict freedoms will appear more and more often despite the fact that the concept of human rights counts on their broadening. 
From the environmental point of view we can object that the concept of human rights, together with the majority of other known forms of the society organization in which the concept (of human rights) can be realized, including the liberal or constitutional democracies (Skolimowski 2006, 234), is too anthropocentric and therefore it doesn't allow a solution for the environmental crisis. Those who reflect on the global environmental crisis from the position of environmental ethics usually point out, that the existing forms of society organization or even the economic, social, and political system of the industrial civilization itself is, together with its negative influence on the environment, a consequence of anthropocentric foundations. The solution for the crisis then should be then overcoming anthropocentrism. Although, as D. Špirko states, the transformation from the prevailing anthropocentric ethics to non-anthropocentric (biocentric) would mean rejection of humanist traditions which allowed a man to be set aside from nature and thus allowed his social emancipation by which he gained a status of a subject having human and civil rights (Špirko 1996, 109). Also P. Jemelka emphasizes that "it is the cutoff from the world of nature that makes a man human. It is also a primary source of all the conflicts that result in the global crisis of environment" (Jemelka 1997, 461). But, as Špirko points out, "slavery could be in its oldest forms born only in conditions of such a social-ethical concept in which a man wasn't set aside from nature and was equal to other creatures" (Špirko 1996, 109). According to Špirko, it was the "nonanthropocentric ethics that created conditions for social inequality and un-freedom" (Špirko 2011, 15), because "slavery appears right after the domestification of some animal species, and possibly at the same time" (Špirko 2011, 14). Opposite to this, "anthropocentric humanism represented a way of emancipation of a man to a human being" (Špirko 1996, 110). Then humanism is "a result of a longterm effort to emancipate human beings, to overcome slavery and other forms of oppression, humiliation, or lack of freedom that were born in the history of human society" (Špirko 2011, 14). Špirko therefore expresses a concern that "the nonanthropocentric concept of ethics with all the proclaimed 'respect for life' - if it concerns the life as such - can become a basis and an apology for different forms of an ecologically motivated "holocaust'" (Špirko 1996, 111). Social inequality is deepening and proposals to leave the constitutional principle of civil equality appear. Instead of solidarity with environmental refugees that would be motivated by humanism we can see more and more anti-immigration moods. Even in countries with deep democratic roots it is not impossible to imagine that some measures would be taken to prevent those running from drought, famine or an increasing plague from coming. ${ }^{14}$

\footnotetext{
14 Very often they are inhabitants of countries with a minimal contribution to the global climatic changes or those at whose expense the increase of production and consumption (and so the increase of production of greenhouse gas and other pollution) took place and
} 
Philosophical reflection on these phenomena must be aware of the fact that even attempts to apply the concept of human rights in the area of political and social law leads to collisions which require consideration between competing claims to basic rights (Habermas 2012, 80). It is more than likely that if the basic rights will include social and also environmental conditions of dignified human existence, there will be many collisions in which it will be necessary to decide between competing claims to the basic rights. And this all despite the fact that the right to water, food, and housing or at least shelter are reckoned as integral to the right to life and other social rights. We are left with several questions. For example, can the right to water, food, and housing be reduced to a right to a general basic income ${ }^{15}$ or can these claims alternate each other? Does the right to water and food imply a rationing system in case of its deficiency? What duties are connected with these rights and whose duties they are? The above mentioned Declaration speaks clearly about the duties of governments (UN 1973, 3) and according to Honneth the primary addressees of the claims are governments (Honneth 2008, 101). Although, Jonas points out that the consent of the public is necessary because especially in democratic countries the legitimacy of public policies is conditioned by the agreement of their inhabitants - the voters. But due to the character and consequences of the steps necessary for at least partial mitigation of the threats connected with the global environmental crisis even $\mathrm{H}$. Jonas is puzzled as to "how can we reach a consensual agreement to necessary

democracy elsewhere could develop. H. Skolimowski talks about "industrial democracy that for one thing loses its original contents and for another can only develop at the expense of others, i.e. thanks to colonialism or slavery, as was the case with the first hundred years of the USA existence. It is an effort to have democracy within one nation and often at the expense of other nations, even if indirectly, through complicated social-economic mechanisms and factors" (Skolimowski 2006, 241). Therefore, Skolimowski states that true democracy is ecocracy or eco-democracy that is an extension of democratic principles to international and inter-species level as the next level in democracy development. And since "human systems must be in accordance with nature systems" (Ibid.), the welfare of humanity should be "supported together with the welfare of other species" (Ibid.). According to Skolimowski the idea of democracy has to be generalized so that it will cover all beings, which would mean that ecodemocracy would become cosmocracy (Ibid., p. 242).

15 The concept of unconditional universal basic income on the level of basic minimum (Van Parijs 2004) is an effort to devise a model of society allowing a man to free himself and his freedom from determinism of the market and its rules. Even though the current constitutional system guarantees a right to work, it does not deal with the fulfillment of the right to life when the individual cannot get a permanent job or does not have a free access to water, food or housing. This argumentation is refused from liberal and neoliberal position, but not necessarily, because reflecting on "the basic income for all" admitted at the end of 1980s also by R. Dahrendorf who declares his support to liberal tradition (Dahrendorf 1991, 288). 
decisions" (Jonas 2011, 906). From the perspective of social inequality or global poverty it will be necessary to work on the concept of human rights and duties connected with them (Flynn 2008). Measures that at least ease the impact of the global environmental crisis would require a greater extent of duties. Fer example a duty not to destroy the environment more than necessary, maybe with a duty to lower the carbon footprint, ${ }^{16}$ which will need to be connected with a restriction of an assumed right to unlimited consumption limited only by the finances of the consumer. L. Sklair emphasizes that „the crisis of ecological unsustainability dictates that this will entail reductions in consumption for those who consume the most all over the world" (Sklair 2009, 87-88). This necessary lowering of consumption, de facto, lowering the standard of living in today's materialistic or consumption sense is one of the main theoretical and practical problems. Their overcoming will decide the character of the future social organization. If the current level of recognition and respect of human rights should be maintained, then restricting the consumption in developed industrial countries should be democratically legitimized ${ }^{17}$. This is justified by the principles of equality in the sense of Rousseau's ideal of society as a free community of equals. Equals not only in the political and legal sense, but also in the sense of an access to basic resources of life, at least to water and food. We should add the principle of environmental equality to the principle of social, political and cultural equality, as M. Hrubec analyzes (Hrubec 2011). A. Krsková emphasizes that "basic rights to freedom and autonomy are subject to limits that constitute freedoms of other and the good of society" (Krsková 2000, 333). Recognition on the social, political and cultural level should mean that the corresponding rights are granted to every individual, but only to the level of common environmental resources or rather their sustain-

\footnotetext{
16 It wouldn't be - at least on the theoretical level - a revolutionary change. E.g. the Constitution of the Slovak Republic since 1992 states in the article 44 the right to "favourable environment" and it even imposes a universal duty to "protect and improve the environment and to foster cultural heritage". The term duty is in the Constitution of the Slovak Republic mentioned only once again with regard to compulsory education and compulsory military service. Paragraph 3 article 44 of the Constitution also states that "no one will imperil or damage the environment, natural resources and cultural heritage beyond the limits laid down by a law". The Constitution admits a certain extent of imperilment and damage of the environment. Legislation laying down the permissible level of devastation and exploitation is very important. But maybe even more important is the ability of the public authority to enforce the compliance with this legislation which in many cases fails already on the national level. Obviously, it is more difficult to enforce on the global level. ${ }^{17}$ According to L. Sklair it is necessary to distinguish between "the culture-ideology of consumerism and rights to adequate consumption. The human right to adequate consumption (we can define this as the basic minimum level that even averagely well-off people would settle for), properly conceived, entails the social responsibility of those who are democratically elected to make such decisions to ensure that is available to all" (Sklair 2009, 87).
} 
nable consumption. This level should not deepen the devastation and disruption of the planetary ecosystem. Even these consequences of the culture-ideology of consumerism spreading by the globalization take away freedom and autonomy from the growing number of people worldwide.

The principle of equality is challenged by another trend - deepening of inequality on the social, political, legal and also environmental level. The deepening inequality will hinder the solution emerging from the application of the principle of equality not only because the overconsumption of the rich minority takes away the resources that would saturate the basic needs of the most poor (who are a majority from the global perspective), but also because the overconsumption of a small group always motivates and stimulates an effort to get equal. Nikita S. Chruščov's motto to "reach and overtake" (the West in production and consumption) has a worldwide effect and we can say that governments of many countries act upon it. The principles of competition then only multiply devastating consequences of such actions on the society and the environment. Therefore, if equality is to be one of the basic principles of the social organization that should be able to overcome the global environmental crisis and will not abandon the concept of human rights, it will be necessary to explain the persisting and deepening inequality, outline arguments in favor of institutions reducing this inequality and try to implement them on a global scale. Otherwise, there is a real threat that the devastated environment will not be the only result of unrestrained growth of the global industrial civilization. The society will be de-humanized as well, and it will be organized in accordance with the right of the fittest ones, which doesn't understand equality; it does not even take it as an ideal.

\section{Conclusion}

While demanding the right of personal freedom available really for all people in the same degree, it is necessary to take into account the fact that the Earth's surface is about 51 billion. Ha, of which we can count around 11.9 billion hectares as realistically usable. It means that for 7.3 billion of people on the Earth about 1.8 hectares of land falls on each individual as the surface to provide housing, transport, production, storage of food and wastes as well as food production, but also oxygen.

However, these calculations do not take into account the spatial and other needs of the rest of living creatures, whose habitat is literally every day truncated by man. At the same time, it relates to the space necessary for maintaining the minimum level of biodiversity necessary for a longterm sustainability of life on the planet. Personal liberties, freedom of consumption, freedom of property and free- 
dom of movement have, therefore, clearly not only political and social, but also environmental limits.

Taking into account that humanity faces with the dilemma - either to leave the concept of universal human rights, or on the contrary, begin to consistently enforce them - not only with the emphasis on the principle of equality and dignity for all people, but also with regard to the principle of environmental sustainability of realization of human rights and freedoms.

Environmentalism can then be understood as a new form of humanism. Humanism in the sense of a longterm struggle for emancipation and mutual recognition is expressed in the concept of human rights. The new perspective opened by the global environmental crisis points out a need to redefine humanism and broaden its meaning to include the environmental aspect. This is not only to preserve life and its conditions, but also to preserve human dignity. Environmentalism points out that a denial of humanity, underestimation of others as equals doesn't have only a form of expelling one from the society, a form of social deprivation or slavery. It also has an indirect form - devastation of the environment, pollution, or depletion of the natural resources. This often happens without a direct personal involvement or intention. For example, it happens in the form of unwanted side effects that happen as a result of increasing living standards through the growth of production and consumption which often means lowered living standards of other people. These lowered standards are far below the line of human dignity and because of the climatic changes or depleted biotopes more and more people find themselves in such situations. As in other areas, the same principle applies here: requiring rights for me should lead to the respect and recognition of the same rights for others. To recognize the rights to a good environment (the right to water, food, and housing) is a sign of humanism as an ideal. Fulfilment of this ideal will require immense social and economic costs. However, if the current functioning model of the industrial civilization keeps destroying the environment and biodiversity, there will not be enough means to prevent it from doing so.

\section{References}

Beck, U. (2010a): Climate for Change, or How to Create a Green Modernity? In: Theory, Culture \& Society, Vol. 27(2-3), 254-266.

BECK, U. (2010b): Remapping Social Inequalities in an Age of Climate Change: for a Cosmopolitan Renewal of Sociology. In: Global Networks 10, 2 (2010), 165181.

CÍLEK, V. (2012): Suroviny a konec světa - od kolapsu k regeneraci. In: Bárta, M. Kovář, M. a kol.: Kolaps a regenerace: Cesty civilizací a kultur. Minulost, současnost a budoucnost komplexních společností. Praha: Academia, 767-786. 
DAHRENDORF, R. (1991): Moderný sociálny konflikt. Esej o politike slobody. Prel. F. Pál. Bratislava: Archa.

DUNAJ, L'. (2014): To Deficits of Democratic Thinking in Slovakia. In JAVORSKÁ, A. - MITTERPACH, K. - SŤAHEL, R. (eds.): Philosophica 14: Rendering Change in Philosophy and Society. Nitra: UKF, 7-20.

DUNAJ, L. (2015): The Pragmatist Approach to Sociocultural Transformation as an Alternative to Neoliberal Radicalism. In: Philosophica Critica, 2015, Vol. 1, No. 2, 19-31.

FLYNN, J. (2008): Lidská práva, transnacionální solidarita a povinnosti vůči globálně chudým. In: Hrubec, M. (ed.): Interkulturní dialog o lidských právech. Západní, islámské a konfuciánské perspektivy. Přel. J. Velek. Praha: Filosofia, 135175.

HABERMAS, J. (2008): K legitimizaci prostřednictvím lidských práv. In: Hrubec, M. (ed.): Interkulturní dialog o lidských právech. Západní, islámské a konfuciánské perspektivy. Přel. A. Bakešova. Praha: Filosofia, 113-133.

HABERMAS, J. (2012): The Concept of Human Dignity and the Realistic Utopia of Human Rights. In: Habermas, J.: The Crisis of the European Union. Translated by Ciaran Cronin. Cambridge: Polity Press, 71-100.

HOHOŠ, L. (2007): Globalization and a Normative Framework of Freedom. In: Human Affairs 17, 42-53.

HOHOŠ, L. (2013): Sme odsúdení žit' na nehostinnej planéte? In: (Úvahy) o l'udskosti a ekologickosti človeka a jeho l'udskej prirodzenosti a podstate. Zborník zo sympózia, Zvolen - 19. septembra 2013. Zvolen: Technická univerzita, 45-50.

HONNETH, A. (2008): Univerzalismus jako morální past? Podmínky a meze politiky lidských práv. In: Hrubec, M. (ed.): Interkulturní dialog o lidských právech. Západní, islámské a konfuciánské perspektivy. Přel. M. Pullmann. Praha: Filosofia, 83-112.

HRUBEC, M. (2010): Preconditions of Intercultural Dialogue on Human Rights. In: Veritas, Vol. 55, No. 1, Jan/Apr 2010, 183-205.

HRUBEC, M. (2011): Od zneuznání ke spravedlnosti. Kritická teorie globální společnosti a politiky. Praha: Filosofia.

JONAS, H. (2011): K ontologickým základům etiky budoucnosti. Přel. P. Bláha. In: Filosofický časopis, roč. 59, 2011, č. 6, 897-908.

JEMELKA, P. (1997): Environmentální etika, antropocentrismus a racionalita. In: Filosofický časopis, roč. 45, 1997, č. 3, 459-468.

KOHÁK, E. (1993): Lidská práva, správnost př́rody. In: Česká mysl, 1993, XLIII (3), 97-106.

KRSKOVÁ, A. (2000): Staronová perspektíva chápania l'udských práv. In: Filozofia, roč. 55, č. 8, 2000, 327-334. 
ROBINSON, W. I. (2014). Global Capitalism and the Crisis of Humanity. Cambridge: Cambridge University Press

ROUSSEAU, J.-J. (2011): On The Social Contract, or Principles of Political Right. In: Rousseau, J.-J.: The Basic Polical Writings. Second edition. Translated and Edited by Donald A. Cress. Indianopolis, Hacket Publishing Company, Inc. 2011, 153-252.

SKLAIR, L. (2009): The Globalization of Human Rights. In: Journal of Global Ethics. Vol. 5, No. 2, August 2009, 81-96.

SKOLIMOWSKI, H. (2006): Kozmokracia ako nový stupeň vo vývoji demokracie.

Prel. T. Cárová. In: Filozofia, 61, (3), 234-246.

SOUSEDÍK, S. (2010): Svoboda a lidská práva. Praha: Vyšehrad.

STEFEN, W. et al. (2015): Planetary Boundaries: Guiding Human Development on a Changing Planet. In Science, 13 February 2015, Vol. 347, no. 6223.

SŤAHEL, R. (2016): Environmental Crisis and Political Revolutions. In: Arnason, J. P. - Hrubec, M. (eds.): Social Revolution and Transformation. Edinburgh: Edinburgh University Press, 99-120.

SWIFT, A. (2005): Politická filozofie. Přel. D. Šmejkalová. Praha: Portál.

ŠMIHULA, D. (2001): O podstate l’udských práv. In: Filozofia, 56, (6), 431-437.

ŠPIRKO, D. (1996): Človek v ústredí, alebo v ústraní? In: Filozofia, 51, (2), 106111.

ŠPIRKO, D. (2011): Biocentrizmus, humanizmus, zodpovednost'. In: Úvahy o biocentrizme a humanizme : zborník zo sympózia, Zvolen - 7. september. Zvolen: Technická univerzita vo Zvolene, 12-19.

ŠPIRKO, D. (2012): Sloboda a „environmentálna zodpovednost'“. In: Suchárek, P. (ed.): Sloboda a jej projekcie. Stará Lesná 2011. Zborník vedeckých príspevkov z jubilejného 10. výročného stretnutia Slovenského filozofického združenia spojeného s medzinárodnou konferenciou. Filozofická fakulta Prešovskej univerzity: Prešov, 182 - 187.

UN (1945): Charter of the United Nations. New York, United Nations. Web. 05.01.2015. http://www.un.org/en/documents/charter/index.shtml

UN (1948): The Universal Declaration of Human Rights. New York: United Nations. Web. 05.01.2015. http://www.un.org/en/documents/udhr/

UN (1966a): International Covenant on Civil and Political Rights. New York: United Nations.

UN (1966b): International Covenant on Economic, Social and Cultural Rights. New York: United Nations. Web. 05.01.2015. http://www.ohchr.org/EN/ ProfessionalInterest/Pages/CESCR.aspx

UN (1973): Report of the United Nations Conference on the Human Environment, 5 - 6 June 1972. New York: United Nations. 
UN (1987): Report of the World Commission on Environment and Development: Our Common Future. New York: United Nations. Web. 05.01.2015. http://www.un-documents.net/wced-ocf.htm ÚSTAVA SR, Z.z. 460/1992.v znení neskorších predpisov.

VAN PARIJS, PH. (2004): Basic Income: A Simple and Powerful Idea for the Twenty-First Century. In: Politics \& Society, March 2004, 32, 7-39.

Acknowledgment: This article is a partial result of VEGA project No. 1/0460/15 „Filozofické fundamenty environmentálneho myslenia a jeho etické, politické, právne a spoločenské konzekvencie"(Philosophical Fundaments of environmental Thinking and its Ethical, Political, Legal and Social Consequences), which is solved by the Department of Philosophy, Faculty of Arts, at Constantine the Philosopher University in Nitra, period 2015 - 2017).

\section{Richard St'ahel, PhD.}

Constantine the Philosopher University

Faculty of Arts

Department of Philosophy

Hodžova 1

94974 Nitra

Slovak Republic

rstahel@ukf.sk 